\title{
POSSIBLE TOXICOLOGICAL EFFECTS ASSOCIATED WITH CHRONIC DERMAL EXPOSURE TO PARA-PHENYLENEDIAMINE (PPD) ON PANCREAS OF ADULT MALE ALBINO RATS
}

\author{
Samah, A. El-Nagdy ${ }^{1}$, Rasha L. Etewa ${ }^{2}$,Eman M. Mohamed $^{3}$, Yara, M. El-Fakharany ${ }^{1}$ \\ ${ }^{1}$ Department of Forensic Medicine and Clinical Toxicology, Faculty Of Medicine, Zagazig \\ University, ${ }^{2}$ Medical Biochemistry, College of Medicine, Jouf University, Sakaka, Saudi \\ Arabia, ${ }^{2}$ Department of Medical Biochemistry, Faculty of Medicine, Zagazig University, ${ }^{3}$ \\ Department of histology\& cell biology, Faculty of medicine, Zagazig University
}

Corresponding Author: Yara M. El-Fakharany

E-mail addresses: dryaratox2012@gmail.com

Postal address: Department of Forensic Medicine and Clinical Toxicology, Faculty of Medicine, Zagazig University, Zagazig, Alsharquiah, Egypt.

Tel.: +201000333163.

Paraphenylenediamine (PPD) is a chemical compound that is commonly used as dark cosmotics and in hair coloring. The aim of this work is to evaluate toxic effect of chronic dermal exposure to PPD on pancreas. Methods: Forty adult male albino rats were used in this study divided into; control group (10 rats) painted on their dorsal sides with $2 \mathrm{ml}$ distilled water and PPD- exposed group (30 rats) was divided into 3 groups; groups I, II and III which were exposed to PPD dermally by painting their dorsal sides with 1,2 , and $3 \mathrm{mg} / \mathrm{kg}$ of PPD respectively (dissolved in $2 \mathrm{ml}$ distilled water) daily for 12 weeks. At the end of the study, all rats were tested for intraperitoneal glucose tolerance test (IPGTT), Hemoglobin A1c (HbA1C) and plasma insulin levels. Histopathological examination and immunohistochemical studies for PCNA and insulin were also performed. Results: The results revealed significant glucose intolerance with decreased level of plasma insulin level in PPD-exposed rats when compared with control group. On histopathological examination, PPD groups showed vacuolations in cells of islets of Langerhans, irregular distorted acini, and congested blood vessels. Immunohistochemical staining revealed weak positive immunoreaction for insulin with significant decrease in area percentage of positive insulin immunoreaction and strong positive immunoreaction for PCNA in groups II and III. Conclusion: It was concluded that chronic dermal exposure to PPD resulted in dose-dependent toxic effects on pancreas, with recommendations to avoid chronic dermal exposure to hair dyes containing PPD and adherence to wear protective gloves when chronic handling of these dyes is necessary.

Keywords: PPD, Pancreas, IPGTT, HbA1C, PCNA.

\section{INTRODUCTION}

Paraphenylenediamine (PPD) has been identified as a hair dye since the end of $19^{\text {th }}$ Century. It is also used as a component in industry of polymers, aramide fibers, fabric colors, pigments and in electronics (Stanley et al., 2005 and Dressler and Appleqvist, 2006).

Over many centuries, dyeing hair with henna which is derived from the leaves of Lawsonia inermis plant was traditionally used among the Egyptians. PPD is either used alone to draw black tattoo on body or added to real henna. Nowadays, regardless of the brand, PPD is present in almost every natural, herbal, artificial or ammonia free hair dyes (Gregory, 2007).

Intentional self-harm or unintentional intoxication from PPD has been reported worldwide especially in developing countries such as Sudan, Morocco, and India (Krishnaswamy and Sooraj, 2009). Because of the health risks associated with use of this chemical, it was banned in many countries such as in Germany, France and Sweden (Chong et al., 2016). 
Acute toxicity with PPD in human was represented in many cases with hypersensitivity reactions, renal failure, metabolic abnormalities, seizures, and coma (Ayesha and Hafiz, 2010). Experimental studies revealed that subchronic dermal exposure to PPD caused impairment in heart, liver and kidney functions which were attributed to oxidative stress and lipid peroxidation (Devi, 2016).

There are no previous reports about chronic dermal exposure to PPD and possible pancreatic toxicity. Only few reports about probable PPD-induced hyperglycemia among repeated hair dye users were recorded (Nohynek et. al., 2010).

The aim of this study is to evaluate the toxic effects of chronic dermal exposure to PPD on pancreas in adult male albino rats through biochemical assessment of intraperitoneal glucose tolerance test as a diagnostic index of glucose intolerance, hemoglobin A1c (HbA1c), and plasma insulin levels. Also, histopathological and immunohistochemical changes of the pancreas were studied.

\section{MATERIALS \& METHODS}

1- Materials:

a-Chemical: Paraphenylenediamine (PPD) (CAS number 106-50-3) from Sigma Chemical Company (St Louis, MO, USA).

b-Experimental animals: The experimental procedure was performed according to Laboratory Animals Care and Use Guide of Zagazig University Animal Ethical Committee. Forty adult albino rats weighing (180-210 gm) were housed in polypropylene cages under an ambient temperature of $21 \pm 3^{\circ} \mathrm{C}$, and they were accommodated to laboratory environment for one week before beginning of the experiment.

\section{2- Methods:}

Forty adult male albino rats were included in the study and were divided as follow:

- Control group: 10 rats were painted with $2 \mathrm{ml}$ of distilled water on their backs after being clipped free of hair for 12 weeks.
- PPD-exposed group: divided into three groups each included 10 rats. The rats were painted on their backs after being clipped free of hair with PPD dissolved in 2 $\mathrm{ml}$ double distilled water (Dawood et al., 2015) daily for 12 weeks. Formulations were prepared daily prior to application. PPD doses used in this study were according to Manuj and Karabi (2010) and Abd-Elzahar et al. (2012) as follow:

Group I: painted with $1 \mathrm{mg} / \mathrm{kg}$.

Group II: painted with $2 \mathrm{mg} / \mathrm{kg}$.

Group III: painted with $3 \mathrm{mg} / \mathrm{kg}$

At the end of the study, blood samples were obtained from medial canthus of the eyes (Renwick 1989) in plain tubes for serum separation and stored at $-20^{\circ} \mathrm{C}$ until analysis for biochemical parameters. Then the rats were anesthetized by $50 \mathrm{mg} / \mathrm{kg}$ of thiopental, sacrificed and pancreatic tissue were excised for histopathological and immunohistochemical evaluation.

a. Biochemical parameters:

a.1. Intraperitoneal glucose tolerance test (IPGTT):

It was carried out at the end of the study. After overnight fasting, dextrose 50 $\%$ at a dose of $2 \mathrm{~g} / \mathrm{kg}$ was injected intraperitoneally, and blood glucose concentration was assessed just before the injection (00 min.) and at 30,60 and 120 min after the injection using a Beckman glucose analyzer (Beckman Instrument Co., Palo Alto, CA) according to Song et al. (2009).

a.2. Measurement of plasma insulin and HbA1c levels:

It was performed at the end of the study. After overnight fasting, blood samples were collected at $00 \mathrm{~min}$ before dextrose injection, then plasma insulin level was measured using radioimmunoassay kit (Dainabot Corporation, Tokyo, Japan) and HbA1c was measured by DCA 2000 Hemoglobin A1c reagent kit (Bayer Health care, Cat No.5035) according to the method described by Song et al. (2009).

b. Histopathological and Immunohistochemical studies:

b.1. Histopathological examination: 
According to Bancroft and Gamble (2008), $5 \mu \mathrm{m}$-thick paraffin sections of pancreas were prepared for Hematoxylin and Eosin (H\&E) stain, then examined by light microscope for evaluation of any pathological changes.

b.2. Immunohistochemical study for proliferating cell nuclear antigen (PCNA):

According to Ramos-Vara et al. (2008), PCNA immunohistochemistry staining was performed using Avidin biotin complex (ABC) method according to manufacturer manual which included incubation of pancreas sections with antiPCNA (mouse monoclonal antibody; Clone PC-10; Code No. M0879; diluted 1:200, Dako). PCNA positive cell number was measured by computer image analyzer system (Leica Ltd, Cambridge, UK).

\section{insulin:}

b.3. Immunohistochemical study for

Immunostaining of pancreatic tissue using Avidin biotin complex (ABC) technique (Dako ARKTM, CAT No. K3954, Dako, Glostrup, Denmark) and Anti-insulin (mouse monoclonal antibody; No. I 2018; dilution 1/1000; SigmaAldrich, Steinheim, Germany) was carried out for measuring area percentage of posive insulin immunoreaction (Ramos-Vara et al., 2008). All slides were examined by light microscope and measured by computer image analyzer system (Leica Ltd, Cambridge, UK).

\section{STATISTICAL ANALYSIS}

Data was analyzed using Social Statistical Package version10 (SPSS Inc., Chicago, IL). Quantitative data were summarized as mean \pm standard deviation $(\mathrm{X} \pm \mathrm{SD})$. Test of significance for quantitative data was done using Anova test for comparison between groups. Least significant difference (LSD) for multiple comparisons (Norusis, 1997).

significance level was considered at $p$ value $<0.05$.

\section{RESULTS}

\section{a- Biochemical findings:}

a.1. Blood glucose concentration $(\mathrm{mg} / \mathrm{dl})$ was significantly increased in groups II \& III on comparison with control group $(\mathrm{p}<0.05)$ at $(00 \mathrm{~min})$ while, no significant difference was detected when group I compared with control group (p>0.05). At $30 \mathrm{~min} ., 60 \mathrm{~min}$. and $120 \mathrm{~min}$, a significant increase in blood glucose concentration was found in all PPD groups when compared with control group $(p<0.05)$ with the highest increase observed in group III exposed to the highest dose of PPD $(3 \mathrm{mg} / \mathrm{kg})$ (Table 1 \& Figure 1).

a.2. Regarding insulin level (uIU/mL), a significant decrease was detected in groups II and III on comparison with control group $(\mathrm{p}<0.05)$ with no significant difference was found when group I was compared with control group (Table 2 \& Figure 2). On the other hand, HbA1c level (\%) was significantly increased in all PPDexposed groups when compared with control group $(p<0.05)$ with the most increase was measured in group III (Table 2 \& Figure 3).

b. Histopathological and immunehistochemical findings:

b.1. Histopathological results:

Hematoxylin and Eosin (H\&E)-stained sections of the pancreas in control group showed arrangement of the glandular parenchyma in typical lobular structures containing serous acini lined by pyramidal cells with basal rounded nuclei and apical acidophilic cytoplasm (figure 4: A, B). Group I displayed some changes in the islets of Langerhans that appeared with some small vacuoles in the cytoplasm and few dark nuclei (figure 4: C). Group II showed acini with many vacuolated rarified cytoplasm and congested blood vessels (figure 4: D). Group III appeared with distorted irregular acini with the islets of Langerhans appeared with some small vacuoles in the cytoplasm and many large vaculations between the cells.

\section{b.2.Immunohistochemical results for} PCNA: 
Regarding immunohistochemistry staining for PCNA, both control group and group I showed few positive nuclear reactions for PCNA (figure 6: A, B). On the other hand, many positive PCNA nuclear reactions were found in groups II \& III (figure 6: C, D) with a statistically significant increase was detected between these groups when compared with either control group or group I ( $\mathbf{p}<\mathbf{0 . 0 5})$ (Table 3). for insulin:

b.3.Immunohistochemical results

Table (1): Statistical comparison among the studied groups as regard mean values of intraperitoneal glucose tolerance test (IPGTT) using ANOVA \& LSD.

\begin{tabular}{|c|c|c|c|c|c|c|}
\hline \multirow[t]{2}{*}{$\begin{array}{l}\text { Groups } \\
\text { Time } \\
\text { Interval }\end{array}$} & & $\begin{array}{c}\text { Control group } \\
\text { (2 ml distilled } \\
\text { water) } \\
\mathrm{N}=10\end{array}$ & $\begin{array}{c}\text { Group I } \\
\text { (1mg/kg } \\
\text { PPD) } \\
\mathrm{N}=10\end{array}$ & $\begin{array}{l}\text { Group II } \\
\text { (2mg/kg } \\
\text { PPD) } \\
\mathrm{N}=10\end{array}$ & $\begin{array}{c}\text { Group III } \\
\text { (3mg/kg PPD) } \\
\mathrm{N}=10\end{array}$ & $\mathrm{P}$ value \\
\hline & \multirow{5}{*}{$\begin{array}{l}\stackrel{\partial}{\infty} \\
\stackrel{+1}{E} \\
\sum_{\Sigma}^{\oplus}\end{array}$} & \multicolumn{5}{|c|}{ Blood Glucose Concentration (mg/dl) } \\
\hline at $00 \mathrm{~min}$. & & $82.3 \pm 6.7$ & $83.6 \pm 3.9$ & $91.9 \pm 5.49^{\mathrm{a}, \mathrm{b}}$ & $97.3 \pm 3.9^{\mathrm{a}, \mathrm{b}}$ & $0.000 *$ \\
\hline at $30 \mathrm{~min}$. & & $229.8 \pm 5.4$ & $314.5 \pm 7.8^{\mathrm{a}}$ & $316.9 \pm 9.9^{\mathrm{a}}$ & $340.5 \pm 18.4^{\mathrm{a}, \mathrm{b}, \mathrm{c}}$ & $0.000 *$ \\
\hline at $60 \mathrm{~min}$ & & $165.5 \pm 21.7$ & $266.1 \pm 6.1^{\mathrm{a}}$ & $281.6 \pm 6.1^{\mathrm{a}, \mathrm{b}}$ & $290.9 \pm 8.2^{\mathrm{a}, \mathrm{b}}$ & $0.000 *$ \\
\hline at $120 \mathrm{~min}$. & & $90.7 \pm 10.9$ & $134.5 \pm 18.7^{\mathrm{a}}$ & $212.9 \pm 23.8^{\mathrm{a}, \mathrm{b}}$ & $233.8 \pm 27.5^{\mathrm{a}, \mathrm{b}}$ & $0.000 *$ \\
\hline
\end{tabular}

$\mathrm{N}$ : number of rats *: significant $(\mathrm{P}<0.05)$ ANOVA.

LSD for repeated measure ANOVA

expressed as letters: a $(\mathbf{p}<\mathbf{0 . 0 5})$ vs control group, $b(p<0.05)$ vs group $\mathbf{I}, \mathbf{c}(\mathbf{p}<0.05)$ vs group II .

Table (2): Statistical comparison among the studied groups as regard mean values of plasma insulin level (uIU/mL) and HbA1c level (\%) using ANOVA \& LSD.

\begin{tabular}{|c|c|c|c|c|c|}
\hline & $\begin{array}{c}\text { Groups } \\
(2 \mathrm{ml} \text { distilled } \\
\text { water }) \\
\mathrm{N}=10\end{array}$ & $\begin{array}{c}\text { Group I } \\
(1 \mathrm{mg} / \mathrm{kg} \\
\mathrm{PPD}) \\
\mathrm{N}=10\end{array}$ & $\begin{array}{c}\text { Group II } \\
(2 \mathrm{mg} / \mathrm{kg} \\
\mathrm{PPD}) \\
\mathrm{N}=10\end{array}$ & $\begin{array}{c}\text { Group III } \\
(3 \mathrm{mg} / \mathrm{kg} \\
\mathrm{PPD}) \\
\mathrm{N}=10\end{array}$ & $\begin{array}{c}\mathrm{P} \\
\text { value }\end{array}$ \\
\cline { 2 - 7 } $\begin{array}{c}\text { Biochemical } \\
\text { parameter }\end{array}$ & $4.1 \pm 0.4$ & $3.8 \pm 0.1$ & $1.8 \pm 0.4^{\mathrm{a}, \mathrm{b}}$ & $1.4 \pm 0.2^{\mathrm{a}, \mathrm{b}, \mathrm{c}}$ & $<0.001^{*}$ \\
\hline $\begin{array}{c}\text { Insulin level } \\
\text { (uIU/mL) }\end{array}$ & $3.6 \pm 0.1$ & $4.2 \pm 0.2^{\mathrm{a}}$ & $4.3 \pm 0.18^{\mathrm{a}}$ & $4.4 \pm 0.19^{\mathrm{a}}$ & $<0.01^{*}$ \\
\hline HbA1c (\%) & & \multicolumn{5}{|c|}{ Mean \pm SD } \\
\hline
\end{tabular}

$\mathbf{N}$ : number of rats $*$ : significant $(\mathbf{P}<0.05)$ ANOVA. $\quad$ LSD for repeated measure ANOVA expressed as letters: a $(\mathbf{p}<0.05)$ vs control group, $b(p<0.05)$ vs group $I, c(p<0.05)$ vs group II.

Table (3): Statistical comparison among studied groups as regard mean values of PCNA positive cells number and area percentage of positive insulin immunoreaction.

\begin{tabular}{|c|c|c|c|c|c|}
\hline \multicolumn{1}{|c|}{$\begin{array}{c}\text { Group } \\
\text { I }\end{array}$} & $\begin{array}{c}\text { Control group } \\
\text { mmuno-histo- } \\
\text { chemistry } \\
\text { water }) \\
\mathrm{N}=10\end{array}$ & $\begin{array}{c}\text { Group I } \\
(1 \mathrm{mg} / \mathrm{kg} \text { PPD }) \\
\mathrm{N}=10\end{array}$ & $\begin{array}{c}\text { Group II } \\
(2 \mathrm{mg} / \mathrm{kg} \text { PPD }) \\
\mathrm{N}=10\end{array}$ & $\begin{array}{c}\text { Group III } \\
(3 \mathrm{mg} / \mathrm{kg} \\
\mathrm{PPD}) \\
\mathrm{N}=10\end{array}$ & $\begin{array}{c}\mathrm{P} \\
\text { value }\end{array}$ \\
\cline { 2 - 6 } & \multicolumn{5}{|c|}{ Mean \pm SD } \\
\hline $\begin{array}{c}\text { PCNA positive } \\
\text { cells number }\end{array}$ & $19.6 \pm 2.1$ & $21.3 \pm 1.9$ & $30.3 \pm 3.7^{\mathrm{a}, \mathrm{b}}$ & $42.6 \pm 5.1^{\mathrm{a}, \mathrm{b}, \mathrm{c}}$ & $0.000^{*}$ \\
\hline $\begin{array}{c}\text { Insulin positive } \\
\text { area percent }(\%)\end{array}$ & $51.2 \pm 2.0$ & $46.3 \pm 1.2^{\mathrm{a}}$ & $38.2 \pm 5.4^{\mathrm{a}, \mathrm{b}}$ & $32.7 \pm 1.6^{\mathrm{a}, \mathrm{b}, \mathrm{c}}$ & $0.000^{*}$ \\
\hline
\end{tabular}

$\mathrm{N}$ : number of rats *: significant $(\mathrm{P}<0.05)$ ANOVA. $\quad$ LSD for repeated measure ANOVA

expressed as letters: a $(\mathbf{p}<0.05)$ vs control group, $b(p<0.05)$ vs group $I, c(p<0.05)$ vs group II

Egypt J. Forensic Sci. Appli. Toxicol.

Vol 20 (3), September 2020. 
Blood glucose concentration in studied groups

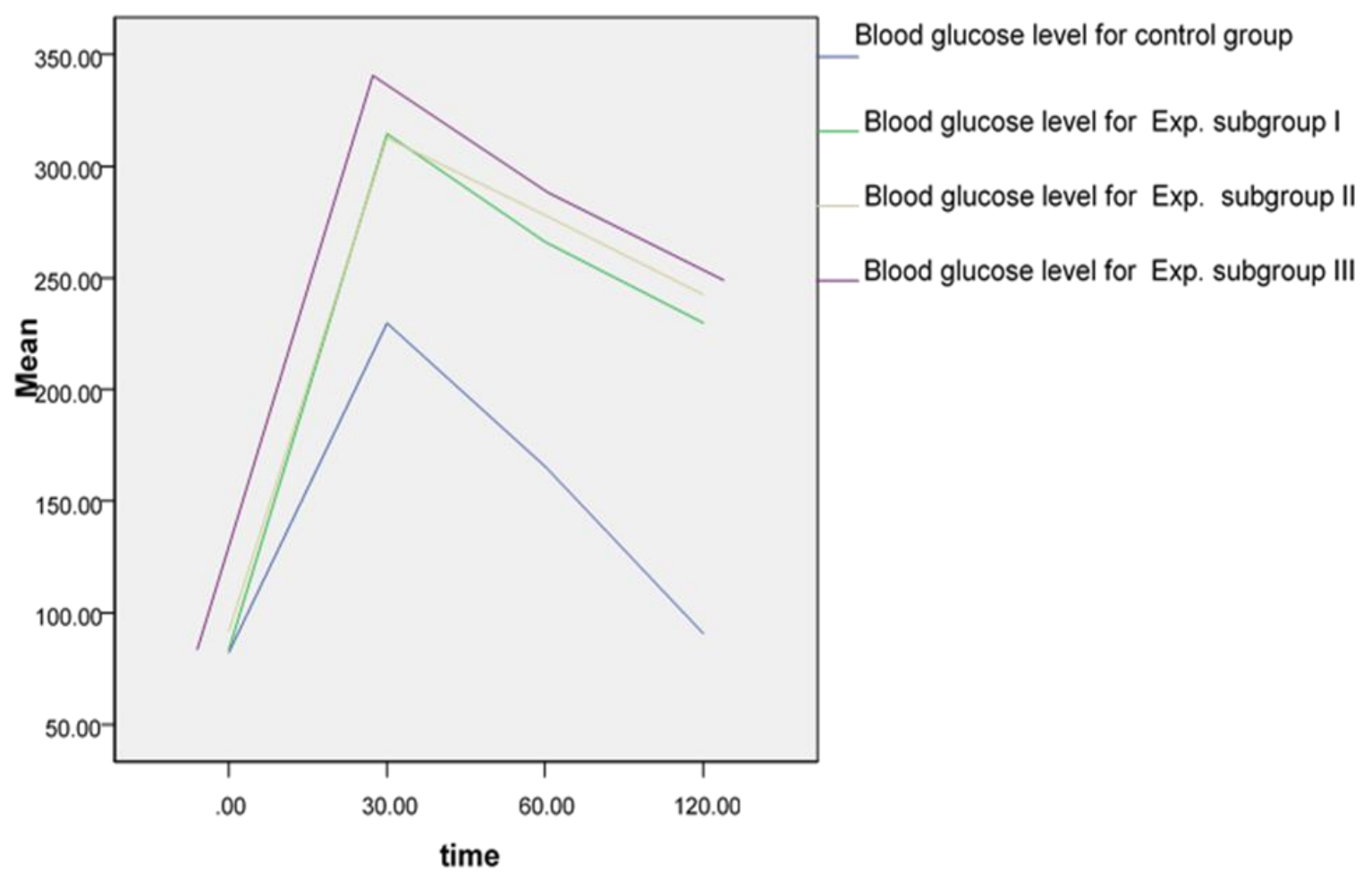

Figure (1): Line chart for mean values of blood glucose concentrations (mg/dl) in the studied groups at $00 \mathrm{~min}, 30 \mathrm{~min}$., $60 \mathrm{~min}$. and $120 \mathrm{~min}$. (IPGTT).

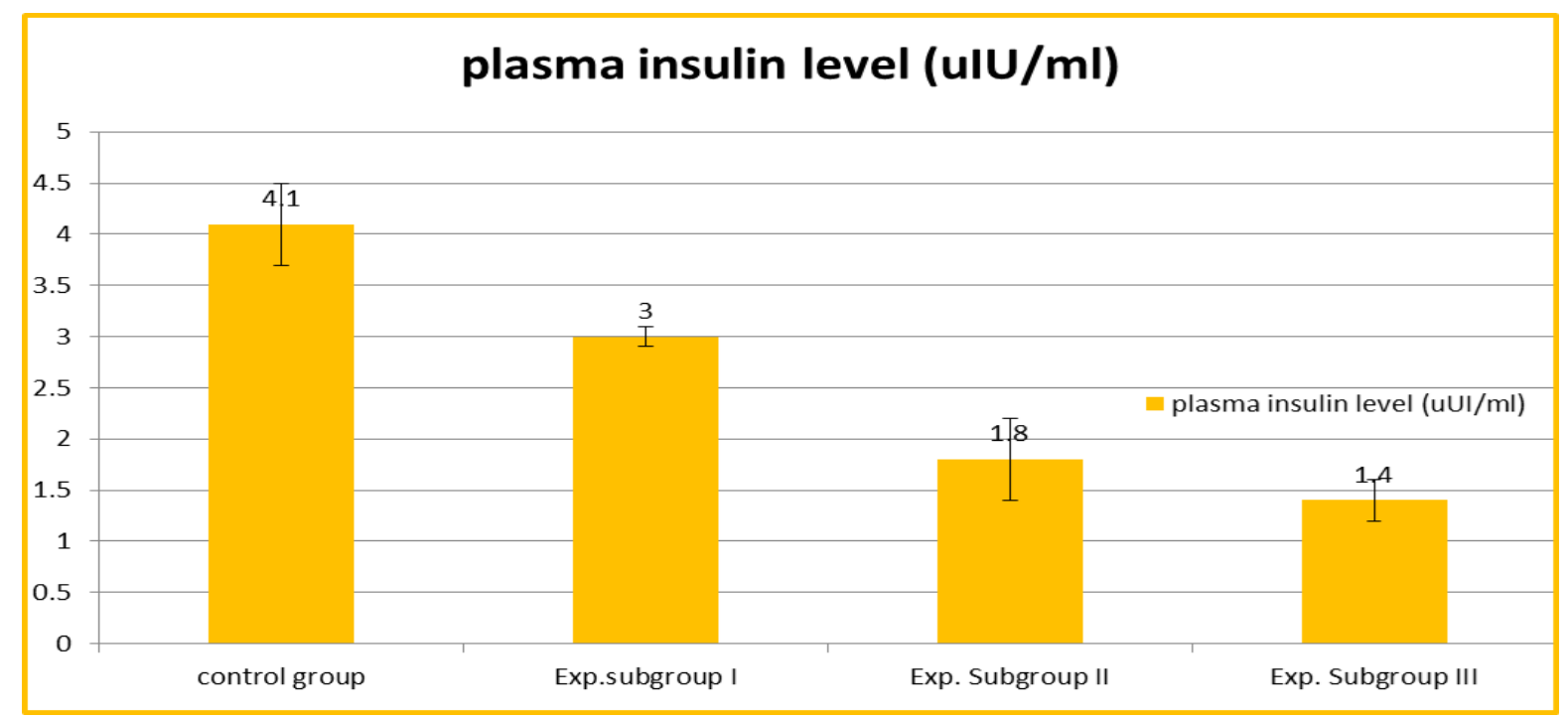

Figure (2): Bar chart for plasma insulin level(uIU/mL) in the studied groups. 


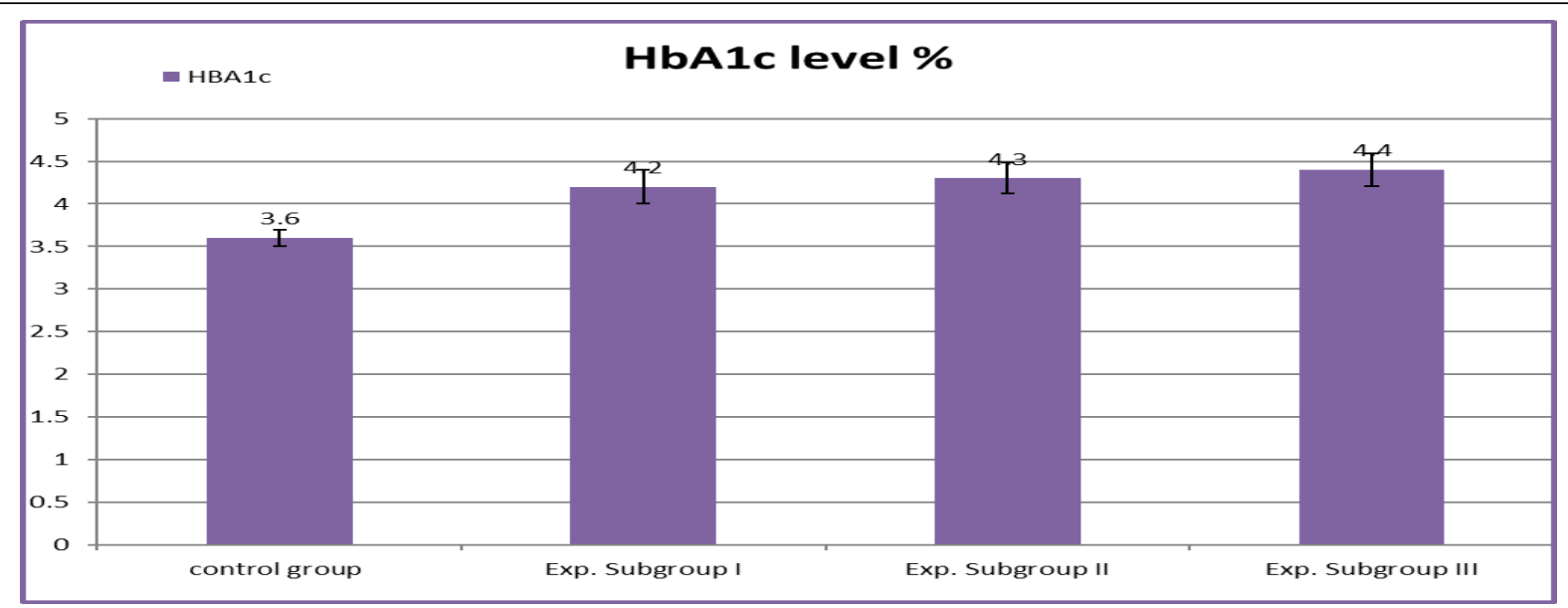

Figure (3): Bar chart for HbA1c level (\%) in the studied groups.

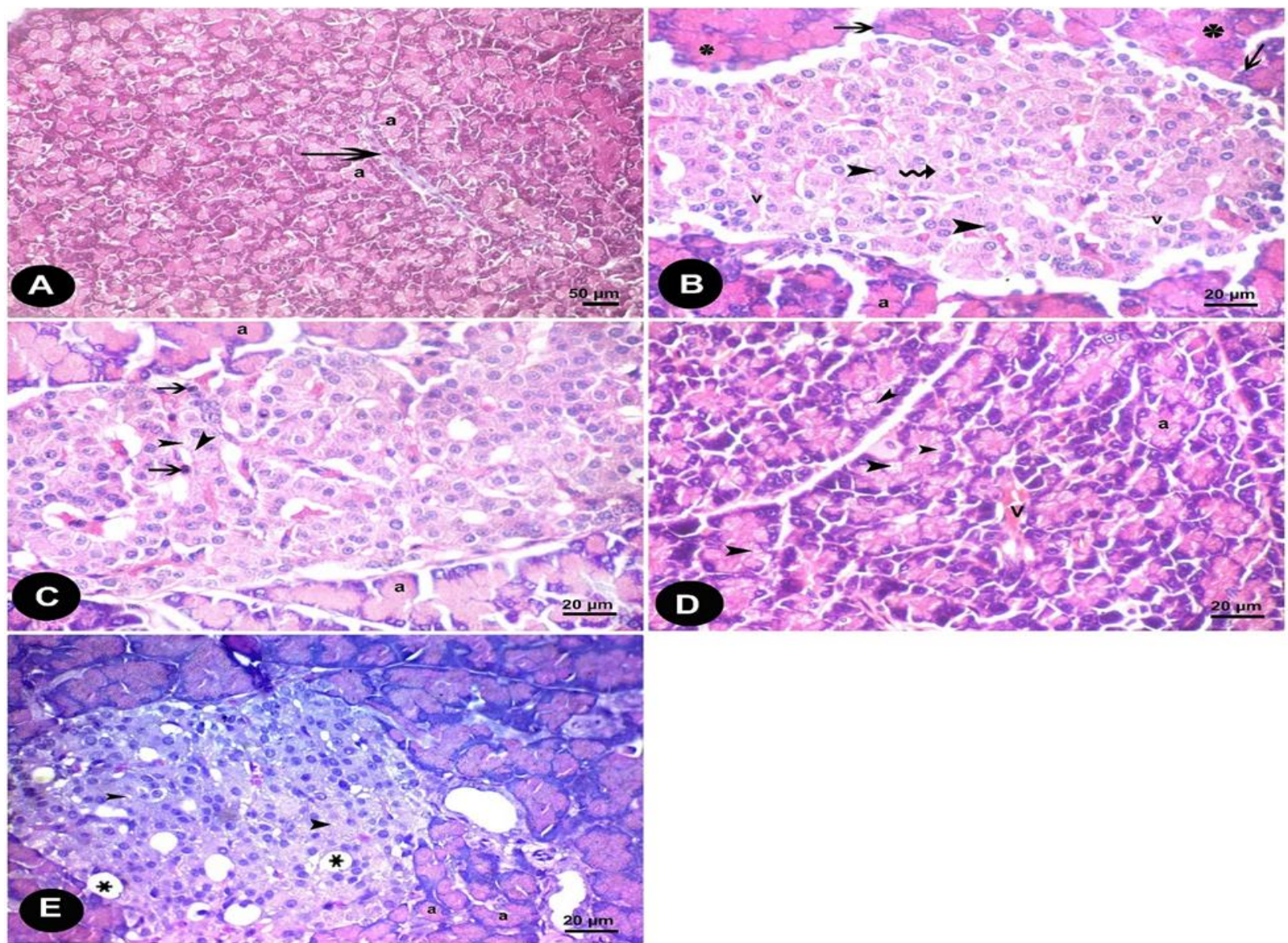

Figure (4): A photomicrograph of sections in pancreas of adult male albino rats of the studied groups. Control group (A\&B): A: General architecture of the pancreas; closely packed serous acini (a), thin septa with thin connective tissue (arrow), B: Serous acini (a) lined by pyramidal cells with basal rounded nuclei (arrow), the apical cytoplasm is acidophilic (star). Islets of Langerhans having pale cytoplasm (zigzag arrow) and nuclei (arrowhead). Blood capillaries (v) are also seen. C: Group I: Normal acini (a) but islets of Langerhans appear with some small vacuoles in the cytoplasm (arrowhead) and few dark nuclei (arrow). D: Group II: Acini (a) having many vacuolated, rarified cytoplasm (arrowhead). Congested blood vessels (V) are obvious. E: Group III: Some distorted irregular acini (a), islets of Langerhans appear with some small vacuoles in the cytoplasm (arrowhead) and large vacuolations between the cells (star). 


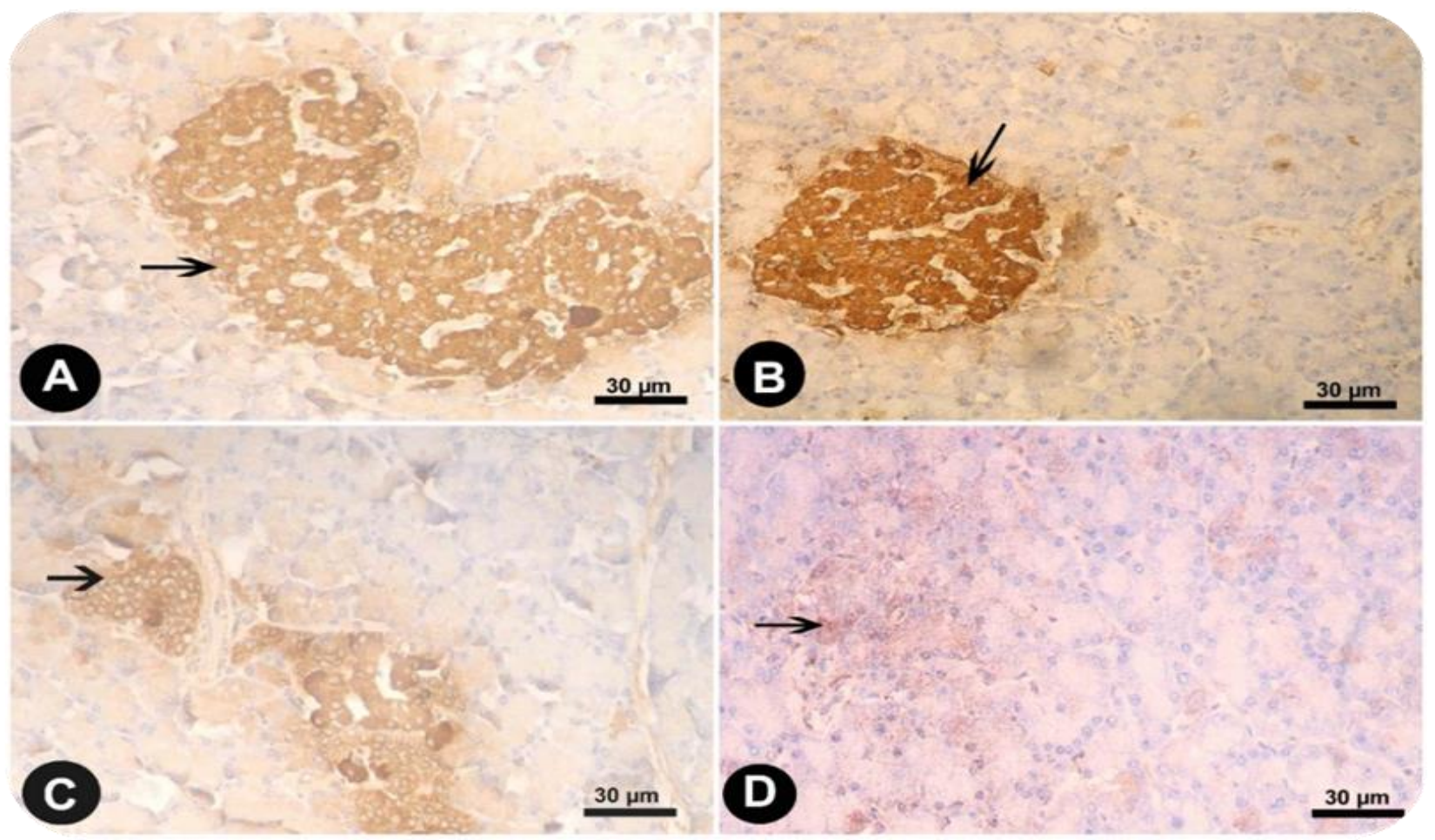

Figure (5): Anti-insulin immunostaining of the pancreas in adult male albino rats of studied groups. A: An islet of Langerhans showing strong positive cytoplasmic immunoreactions of the $\beta$-cells of the control group (arrow); B: Strong positive immunoreaction in group I (arrow). C: Weak positive immunoreaction in group II (arrow). D: Weak positive immunoreaction in group III (arrow).
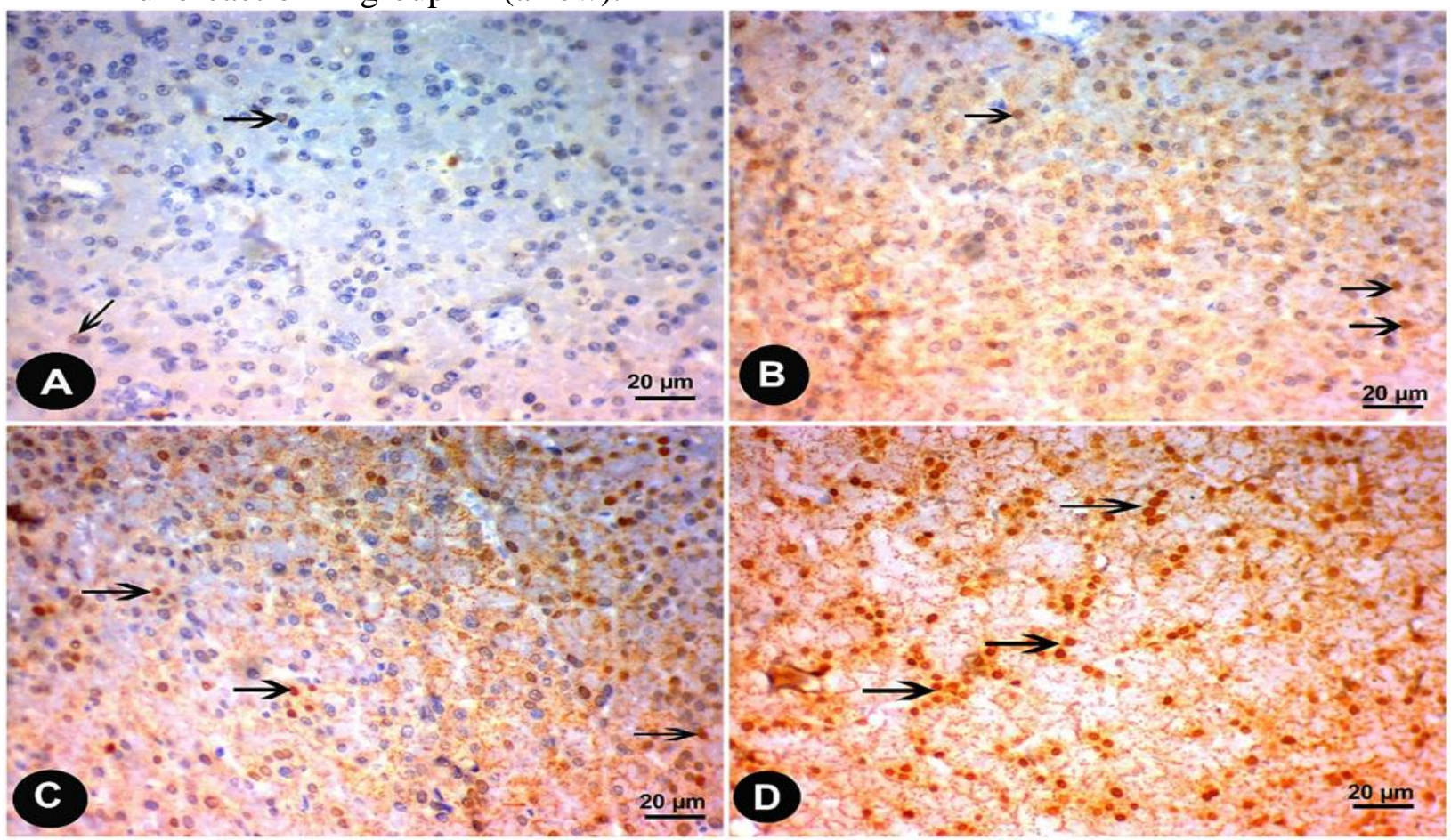

Figure (6): Anti-pena immunostaining of the pancreas in adult male albino rats of studied groups. A: Few positive nuclear reactions in the control group (arrow). B: Few positive nuclear reactions in group I (arrow). C: Many positive nuclear reactions in group II (arrow). D: Many positive nuclear reactions in group III (arrow). 


\section{DISCUSSION}

Paraphenylene-diamine is a widely used chemical mainly in hair dyes, temporary tattoos, dark colored cosmetics, photographic developing solutions, photocopying, printing ink and black rubber. Severity of PPD toxicity depends on the amount involved and the nature of exposure. Possible toxic effects due to chronic exposure occur especially with repeated topical application or inhalation of powdered hair formulations during dyeing process (Yoshio et al., 2003, Lind et al., 2005 and Manuj et al., 2012).

The aim of this study was to investigate the hypothesis of toxic effects of chronic dermal exposure to PPD on pancreas.

In this study, chronic dermal exposure to PPD resulted in significant increase in both blood glucose concentration and HbA1c level in a dose-dependent manner with the highest increase was detected in group III received the highest dose of PPD $(3 \mathrm{mg} / \mathrm{kg})$. Also, a significant decrease in plasma insulin level was found in groups II and III. These results agree with AbdElzahar et al. (2012) and Devi (2016) who reported hyperglycemia following subchronic dermal exposure to PPD in albino rat which was dose-dependent. Also, a study carried out by Sangeetha and Karthi (2010) revealed a significant elevation of random blood sugar in PPD users when compared to control.

The increase in blood glucose concentration \& HbA1c in this study was accompanied by pathological changes in pancreatic cells appeared as rarified cytoplasm, dark cells and many vacuolations together with decreased pancreatic beta islet cell mass evidenced by decreased percent of insulin immune reactivity area. These results are in accordance with those carried out by Saad et al. (2000) and Abd-Elzahar et al. (2012) who reported that dermal exposure to PPD for 30 days resulted in multivisceral toxicological effects including moderate to severe chronic inflammation of the pancreas
Vacuolations in acinar cells and islet's of Langerhans seen in this study could be explained by electrolytes disturbance caused by affection of membrane permeability which led to increase in $\mathrm{Na}+$ and water entrance to the cells (Halliwell and Chirico, 1993). Prasad et al. (2011) also reported release of calcium ions from smooth endoplasmic reticulum causing irreversible changes in cell structure with toxicity of a hair dye containing PPD

The appearance of dark cells and rarified cytoplasm with PPD exposure were explained by Chen et al. (2010) who reported DNA fragmentation and cell cycle arrest. In addition, Al -Seigini et al. (2014) stated that repeated dermal exposure to PPD induced significant DNA damage in peripheral blood lymphocytes in a dose and time dependent manner.

PPD also has been shown to induce single strand DNA and micronuclei disruptions with destabilization of cell lysosomes and release of cathepsin B which when conform to its active form, it induces cytochrome release from mitochondria and successively induces apoptosis (Goyal et al. 2015). Moreover, Kasi et al. (2015) illustrated that PPD created apoptosis via PTK/Ras/Raf/JNK-dependent pathway.

Also, vascular congestion appeared in this work was suggested by Manuj et al. (2012) because of intra vascular blood hemolysis caused by PPD. They added that the rate of bioaccumulation with repeated exposure to PPD is an important factor increasing its toxicity especially after metabolization into acetylated derivatives.

Norman et al. (2006) and Joselyn et al. (2018) stated that $\beta$-Cell mass in the pancreas is a key factor in synthesis, storage, and secretion of insulin for the maintenance of normal blood glucose concentrations; so any change in its structure affects the function and subsequently blood glucose level.

Immunohistochemical results for antiPCNA antibodies in this study revealed significant increase of PCNA expression 
indicating increased cell proliferation activity in PPD exposed rats.

Wang (2014) mentioned that PCNA is a nuclear factor involved in DNA replication, thus regulating processes of apoptosis and glycolysis. Stemmer et al. (2009) also stated that apoptotic cellular death due to toxins stimulates cellular proliferation as a compensatory mechanism for cell loss. Unfortunately, increases in PCNA expression may result in disruption of growth control and may lead to malignant transformation (Boehm et al., 2016 and Reena et al., 2016).

\section{CONCLUSION}

The present work indicated that chronic dermal exposure to PPD resulted in dose dependent toxic effects on pancreas of adult male albino rats. This was evidenced by abnormalities detected in biochemical parameters together with histopathological and immunohistochemical changes.

\section{RECOMMENDATIONS}

It is recommended to replace PPD containing dyes with less risky ones with offering adequate protection on handling hair dyes especially in cases of occupational exposure by wearing suitable protective gloves. Also, Further studies are required to verify the possible mechanisms of PPD induced hyperglycemia and pancreatic toxicity.

\section{REFERENCES}

Abd-Elzahar, M. ; Atef, F. I.; Ahmed, H. M.; Abd-Allah, A. M. and Gayyed, M. F. (2012): Some toxicological health hazards associated with subchronic dermal exposure to paraphenylenediamine (PPD): An experimental study. Egypt J Forensic Sci.; 2(3):105- 111.

Al -Seigini A.; ElSayed, A.; ElHelaly, H. and Abdelhakim, E. (2014): Assessment of DNA Damage on Adult Albino Rats Induced by Dermal Exposure to P-Phenylenediamine (PPD). Ain Shams J Forensic Med Clin Toxicol, (23):173-181.

Ayesha, A. and Hafez, A. (2010): Determination
Phenylenediamine (PPD) in Henna in the United Arab Emirates. Int J Environ Res Public Health.; 7(4):16811693.doi: 10.3390/ijerph7041681.

Bancroft, J.D. and Gamble, M. (2008): Theory and Practice of Histological Techniques. 6th Edition, Churchill Livingstone, Elsevier, China.

Boehm, E.M.; Gildenberg, M.S. and Washington, M. T . (2016): The Many Roles of PCNA in Eukaryotic DNA Replication. Enzymes;39:231-254. doi: 10.1016/bs.enz.2016.03.003.

Chen, S. C.; Chen, C. H.; Tioh, Y.L. , Zhong, P. Y.; Lin, Y. S., et al. (2010): Paraphenylenediamine induced DNA damage and apoptosis through oxidative stress and enhanced caspase8 and -9 activities in Mardin-Darby canine kidney cells. Toxicol In Vitro 24: 1197-1202. doi: 10.1016/j.tiv.2010.02.011.

Chong, H. P.; Reena, K.; Khuen, Y. N.; Koh, R. Y.; Chew, H. N. et al. (2016): para-Phenylenediamine Containing Hair Dye: An Overview of Mutagenicity, Carcinogenicity and Toxicity. J Environ Anal Toxicol; 6:403. doi: 10.4172/21610525.1000403.

Devi, M. (2016): Toxicological Effects of Hair Dye Paraphenylene diamine: a Threat to the Cosmetic World. Luminescence; $\quad 1$ : 44-45. Luminescence; 1: 44-45.

Dressler, W.E. and Appelqvist, T. (2006): Plasma/blood pharmacokinetics and metabolism after dermal exposure to para-aminophenol or paraphenylenediamine. Food Chem Toxicol ;44: 371- 379.

Goyal, S.; Amar, S. K.; Dubey, D.; Pal, M. K.; Singh, J. et al. (2015): Involvement of cathepsin B in mitochondrial apoptosis by pphenylenediamine under ambient UV radiation. J Hazard Mater 300: 415425.

doi:

10.1016/j.jhazmat.2015.07.032. 
Gregory, S. (2007): Type IV hypersensitivity reaction to a temporary tattoo. Proc Bayl Univ Med Cent.; 20(1): 36-38.

Halliwell, B. and Chirico, S. (1993): Lipid peroxidation: Its mechanism, measurement, and significance. Am J Clin Nutr. 1993;57(5):715S-724S. doi: 10.1093/aicn/57.5.715S.

Joselyn, R.; Valmore, B.; Jim, P.; María, S. M.; Luis, C. O.; Manuel, N. et al. (2018): Pancreatic Beta Cell Death: Novel Potential Mechanisms in Diabetes Therapy. J Diabetes Res.; 2018:9601801. doi: 10.1155/2018/9601801.

Kasi, R. A. ; Moi, C. S.; Kien, Y. W.; Yian, K. R. and Chin, N. W. (2015): Paraphenylenediamine-induces apoptosis via a pathway dependent on PTK-RasRaf-JNK activation but independent of the PI3K/Akt pathway in NRK-52E cells. Mol Med Rep 11:2262-2268. doi.org/10.3892/mmr.2014.2979.

Krishnaswamy, S. and Sooraj, Y. (2009): Hair dye poisoning and the developing world.J Emerg Trauma Shock; 2(2): 129-131. doi: 10.4103/09742700.50749 .

Lind, M. L.; Boman, A.; Sollenberg, J. ; Johnsson, S. ; Hagelthorn, G. , and Meding, B. (2005): Occupational dermal exposure to permanent hair dye among hairdressers. Ann Occup Hyg; 49 : 473-480.

Manuj, Kr. And Karabi D. (2010): Hematotoxic and genotoxic effect of para phenylenediamine after subchronic topical application in rats. The Bioscan 5(4): 585-590.

Manuj, Kr. B.; Rajeev, B.; Taibur, R. and Karabi, D. (2012): Repeated Topical Application of paraPhenylenediamine Induces Renal Histopathological Changes in Rats. Toxicol Int.; 19(2): 132-137. doi: 10.4103/0971-6580.97206.

Nohynek, G.J.; Antignac, E. ; Thomas, R. and Tourtain H. (2010): Safety assessment of personal care products cosmetics and their ingredients. Toxicol Appl Pharmacol; 243: 239259. Doi: $10.1016 / \mathrm{j}$, taap.

Norman, R. S.; Fabiola, S.; Piotr, W.; Antonella, M.; Anthony, R.; Alan, $H$. et al. (2006): Visualizing pancreatic $\beta$ cell mass with $\left[{ }^{11} \mathrm{C}\right] \mathrm{DTBZ}$. Nucl Med Biol; 33(7):855-864. doi: 10.1016/j.nucmedbio.2006.07.002

Norusis, M. J. (1997): Statistical package for science (SPSS) version 10 for windows user's guide's Chicago.

Prasad, N.R.; Bitla, A. R.; Manohar, S. M. Harini; Devi, N. and Rao, P. S. (2011): A Retrospective Study on the Biochemical Profile of Self Poisoning with a Popular Indian Hair Dye. J. Clini. Diag. Res., 5: 1343-1346.

Ramos-Vara, J. A.; Kiupel, M.; Baszler, T.; Bliven, L.; Brodersen, B.; Chelack, B., et al. (2008): Suggested guidelines for immune-histochemical techniques in veterinary diagnostic laboratories. J Vet Diagn Invest.;20(4):393-413.

Reena, K.; Koh, R. Y.; Gnanajothy, P. and Chye, S. M. (2016): ParaPhenylenediamine induces apoptosis through activation of reactive oxygen species-mediated mitochondrial pathway, and inhibition of the NF-I ${ }^{\circ} \mathrm{B}$, mTOR, and Wnt pathways in human urothelial cells. Environ Toxicol. 32(1):265-277. doi: 10.1002/tox.22233.

Renwick, A. G. (1989): Pharmaco-kinetics in Toxicology. In principal \& methods: of Toxicology. 2nd ed. Hayes WZ Avoreu Press: pp 764.

Saad, H. A.; Mousa, H. M. and Ali, B. H. (2000): Some toxicological observations on phenylenediamine (hair dye) in rats and chickens. Pak $\mathbf{J}$ Biol Sci, 3: pp. 953-956.

Sangeetha, R. and Karthi, N. (2010): Topical application of hair dye containing paraphenylene diamine evaluation of antioxidant status and renal parameters in diabetic and non- 
diabetic users. Pharmacologyonline 3: 285-290.

Song, H. K.; Han, D. H.; Song, J. H.; Ghee, J. Y.; Piao, S. G.; Kim, S. H. et al. (2009): Influence of sirolimus on cyclosporine-induced pancreas islet dysfunction in rats. Am J Transplant.;9(9):2024-2033. doi: 10.1111/j.1600-6143.

Stanley, L. A.; Skare, J. A.; Doyle, E.; Powrie, R. N. and Angelo D. (2005): Lack of evidence for metabolism of pphenylenediamine by human hepatic cytochrome P450 enzymes. Toxicol.; 210:147-157.
Stemmer, K.; Ellinger-Ziegelbauer, H.; Ahr, H. J. and Dietrich, D.R. (2009): Molecular characterization of preneoplastic lesions provides insight on the development of renal tumors. Am. J. Pathol. 175, 1686-1698. doi: 10.2353/ajpath.2009.081071.

Wang, S C. (2014): PCNA: a silent housekeeper or a potential therapeutic target? Trends Pharmacol Sci; 35: 178186. doi: 10.1016/j.tips.2014.02.004.

Yoshio, T.; Horiike, N.; Onji, M. ; Undea, T. ; Kumagi, T.; Abe, M. , et al. (2003): Drug induced hepatitis due to repeated use of hair dye. Intern Med, 42; 1104-1106. 
الاثار السمية المحتملة المرتبطة بالتعرض المزمن للبار افنيلين داي امين عن طريق الجلد على البنكرياس في ذكور الجرذان البيضاء البزاء البالغة

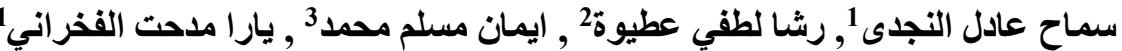

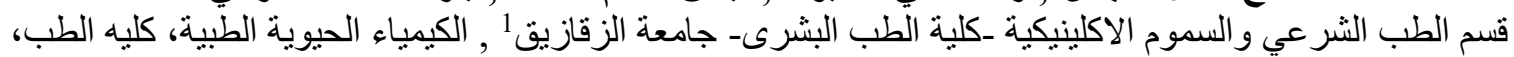

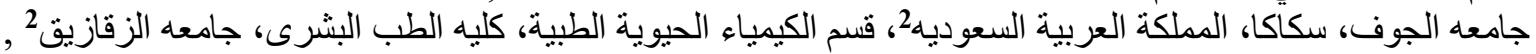

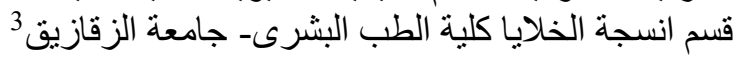

يعتبر البار افنيلين داي امين من المواد الكيميائية شائعة الاستخدام في صبغات الثنعر ومستحضرات التيات التجميل الداكنة.

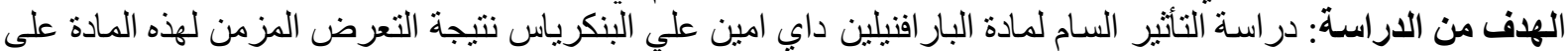

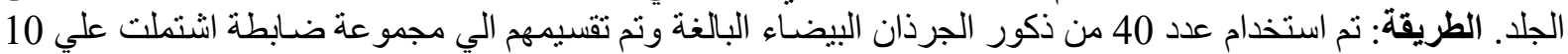

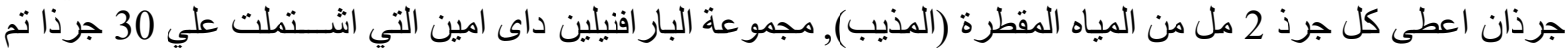

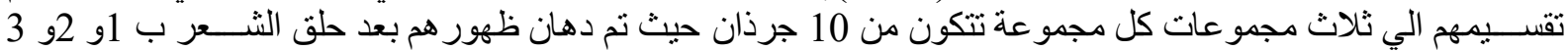

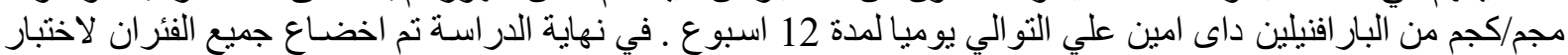

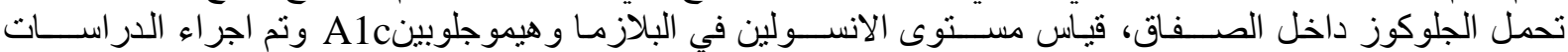

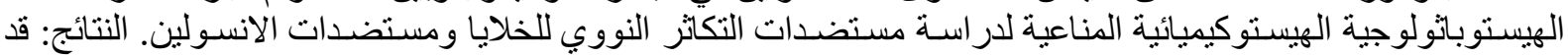

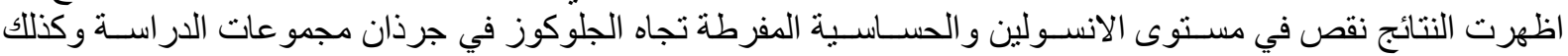

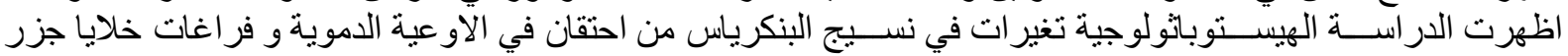

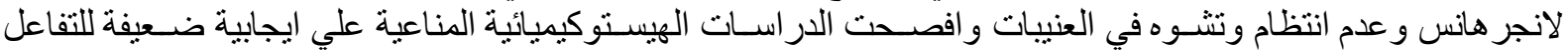

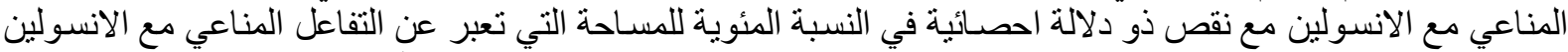

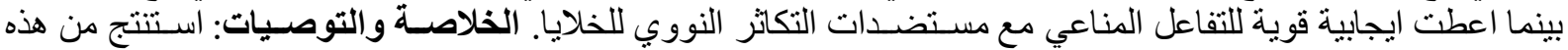

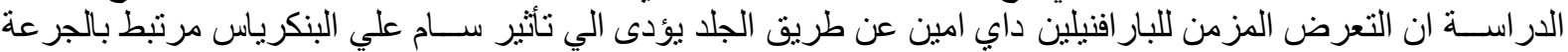

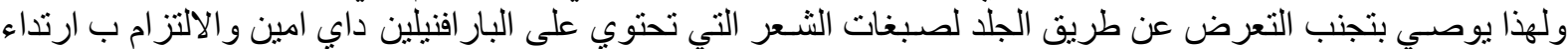
قفاز ات عند ألضرورة. 